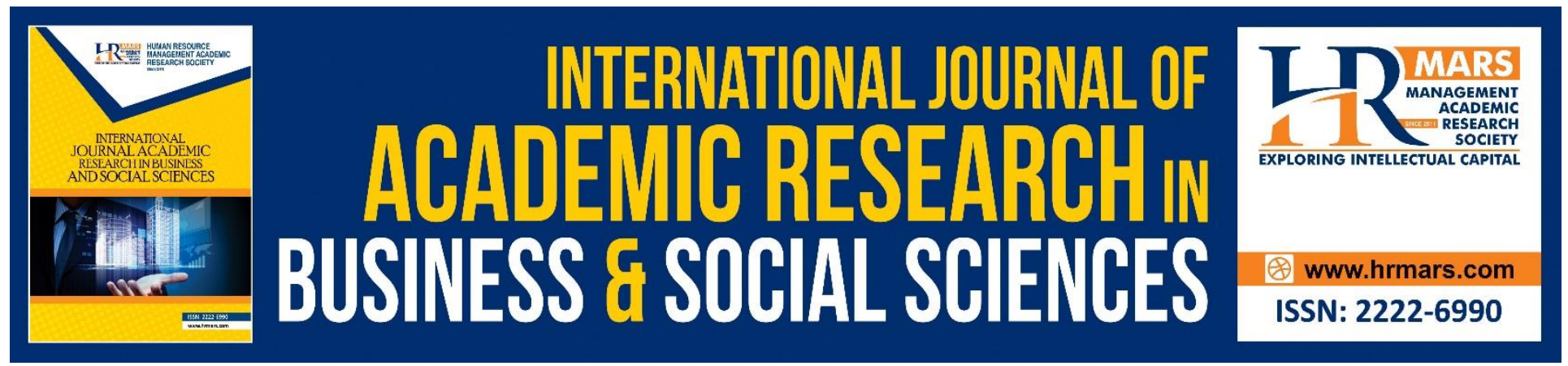

\title{
Building a Conceptual Model for E-CRM Implementation Strategy
}

\section{Mufleh Amin AL Jarrah, Ghassan Issa Alomari, Samer Fawaz Alhawari, Malek Alharafsheh}

To Link this Article: http://dx.doi.org/10.6007/IJARBSS/v10-i1/6834

DOI:10.6007/IJARBSS/v10-i1/6834

Received: 21 December 2019, Revised: 01 January 2020, Accepted: 15 January 2020

Published Online: 29 January 2020

In-Text Citation: (Jarrah et al., 2020)

To Cite this Article: Jarrah, M. A. AL, Alomari, G. I., Alhawari, S. F., Malek, \& Alharafsheh. (2020). Building a Conceptual Model for E-CRM Implementation Strategy. International Journal of Academic Research in Business and Social Sciences, 10(1), 180-193.

\section{Copyright: (c) 2020 The Author(s)}

Published by Human Resource Management Academic Research Society (www.hrmars.com)

This article is published under the Creative Commons Attribution (CC BY 4.0) license. Anyone may reproduce, distribute, translate and create derivative works of this article (for both commercial and non-commercial purposes), subject to full attribution to the original publication and authors. The full terms of this license may be seen at: http://creativecommons.org/licences/by/4.0/legalcode

\section{Vol. 10, No. 1, 2020, Pg. 180 - 193}

Full Terms \& Conditions of access and use can be found at http://hrmars.com/index.php/pages/detail/publication-ethics 


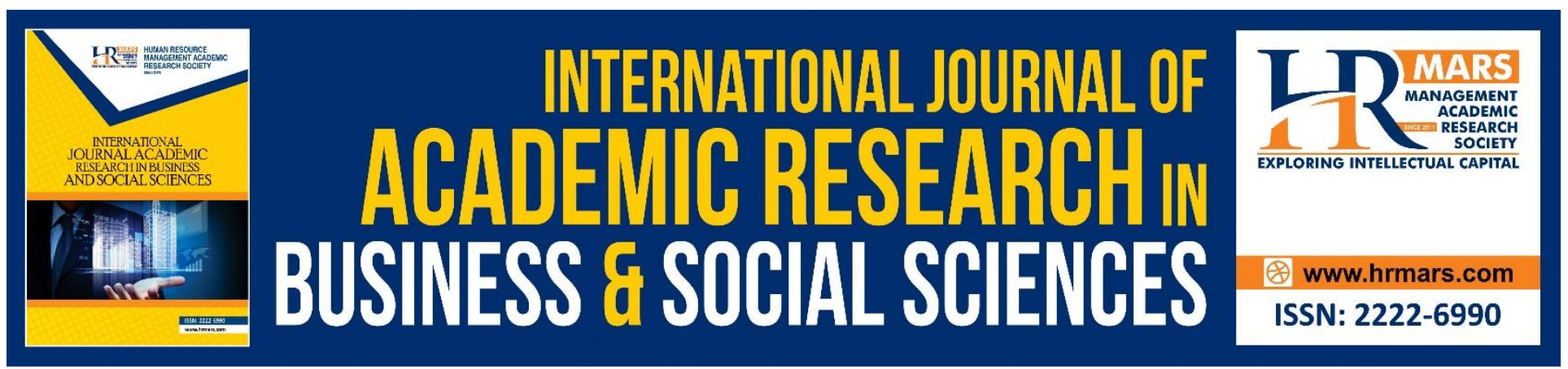

\title{
Building a Conceptual Model for E-CRM Implementation Strategy
}

\author{
Mufleh Amin AL Jarrah, Ghassan Issa Alomari \\ Amman Arab University. \\ Email:muflehj@yahoo.com,ghassanomari@aau.edu.jo
}

\author{
Samer Fawaz Alhawari \\ The World Islamic Sciences and Education University \\ Email: samer.alhawari@yahoo.com \\ Malek Alharafsheh \\ Amman Arab University \\ Email: alserhan@aau.edu.jo
}

\begin{abstract}
The relevance of Information Technology (IT) on Electronic Customer Relationships (E-CRM) within the implementation strategy can be emphasized. This E-CRM implementation strategy is the result of the innovative process related to electronic customers and organizations. However, achieving excellence and the correct deployments of the E-CRM implementation strategy requires rethinking of the E-CRM strategy on a different level in the E-CRM process. To achieve this goal, this paper suggests a conceptual model for E-CRM implementation strategy, focused on all stages from E-CRM mission to E-CRM strategy at different levels (operational, analytical, and collaborative) and connected with E-CRM process (electronic customer acquisition, electronic customer retention, and electronic customer expansion). This in order to increase the customer orientation strategy, customer intelligent strategy, and knowledge capture strategy to reach to the vision of E-CRM. Additionally, the stages presented in this paper may help managers in designing an E-CRM implementation strategy to achieve higher innovation, effectiveness, efficiency, and profitability based on the nature of the underlying electronic marketing activities and the new database technology used for communication with customers.
\end{abstract}

Keywords: E-CRM Strategy, E-CRM Level, E-CRM Process, Customer Orientation Strategy, Customer Intelligent Strategy, and Knowledge Capture Strategy.

\section{Introduction}

The main objective of this study is to build a conceptual model of E-CRM. 
INTERNATIONAL JOURNAL OF ACADEMIC RESEARCH IN BUSINESS AND SOCIAL SCIENCES Vol. 10, No. 1, Jan, 2020, E-ISSN: 2222-6990 @ 2020 HRMARS

Integrating the Electronic Customer Relationship (E-CRM) strategy into an organization can enhance the relationship between the organization and the customers, which sustains a long and lasting collaboration in the electronic environment. Recently, Kaimer and Brune (2018) noted that the effects for the development of web technology such as the CRM structure have rarely been studied in scientific literature. Aghazadeh (2015); Mokhtar, Shaifuddin, Saman, \& Baba, (2018); Al Shbail, (2018), noted that the marketing strategies appear to be a significant kind of resource-based view (RBV) and market-based view organizations could develop marketing strategies based on their internal capabilities and external position.

Additionally, Mekkamol et al., (2013) explained that the concept of websites delivering the important interface for customer use of the internet. Customer Relationship Management (CRM) rises to the executive phase that the businesses have used to produce good work. Navimipour and Soltani (2016) agreed and said that the concept of E-CRM has arisen as a unique example of the most prominent information systems which allow businesses to connect with clients and collect, store, and scrutinize customer information in order to bring about a whole picture of their customers.

It's clear that the implementation strategy, by development of the IT infrastructure, can bring about significant competitive advantages to organizations in the developing world. Furthermore, Varajão and Cruz-Cunha (2016) noted that the concept of CRM is presently a grouping of business and marketing strategies that integrates persons, procedures, Information Technology, and business functions for the purpose of acquiring and retaining customers, providing analytical abilities, reducing costs, and growing profitability. Bahrami et al., (2012) proclaim that CRM can't be successful without considering IT development as a strategy to reach information by customer's data collecting, examine them with concern to customers over real using of IT tools, generate real relationships with customers, and eventually help organizations in attaining long-term benefits. Another study by Giannakis-Bompolis and Boutsouki (2014) noted that the advent of the 21st period is noticeable by the outline of a fresh generation of technology and media in consumers' ordinary life, presenting original performing choices and communication opportunities by focusing on CRM strategy.

Additionally, IS research using RBV has largely focused on classifying information-based resources along the attributes of resources value, rarity, imitability, substitutability, and mobility, posited by RBV with a view towards understanding which IS resources are most likely to contribute to competitive advantage (Wade and Hulland, (2004). Therefore, IT has changed the ways organizations work and the CRM process is a revolution which, combined with the strategy, has enhanced the CRM performance. In a study, Bahari and Elayidom (2015) argue that many of the procedures and additional valuable structures in CRM assist in evolving a corporate approach. This business method recognizes and affects the client actions over significant communications to enhance the customer acquisition stage, customer retention stage, customer loyalty, and customer profitability. Additionally, the concept of CRM can be defined as a complete strategic technique of enhancing owners' value over the improvement of suitable relationships with key customers, to acquire and work with customers, and to create additional profitability for the businesses (Alhawari et al, (2016) ; Ahani et al., (2017). Moreover, Reddick (2011) implied that CRM with IT has the capability to join the client service purpose into integrated IT, with emphasis on the requests of people since client service representatives become experts in classifying their requirements. From this point, Trainor et 
INTERNATIONAL JOURNAL OF ACADEMIC RESEARCH IN BUSINESS AND SOCIAL SCIENCES

Vol. 10 , No. 1, Jan, 2020, E-ISSN: 2222-6990 @ 2020 HRMARS

al., (2013) explain that CRM systems with new technology has resulted in a new concept of CRM which integrates a more collaborative and communicative ways of dealing with customer relationships.

However, the electronic environment and the internet technology are unique forms of media that allows knowledge to be accessed without the constraints of geographic location. This makes the ECRM implementation strategy applicable in the international markets. Yu et al (2015) defines the ECRM as an association of hardware, software, processes, and applications, along with a wider management commitment to use the internet to grow both the scale and choices of customer services.

Gaining a better relationship with customers in an electronic environment requires the use of IT within all processes and levels of the organization; the purchase of goods and services through the internet affects CRM performance. Therefore, this paper advances research on E-CRM implementation strategy by suggested a conceptual model which describes the mission of E-CRM, including all stages in implementing this E-CRM strategy at different levels (operational, analytical, and collaborative). It is connected with E-CRM processes (electronic customer acquisition, electronic customer retention, and electronic customer expansion) in order to develop the customer orientation strategy, customer intelligence strategy, and knowledge capture strategy to reach the vision of the E-CRM. Identification of such processes will shed light to the online customer relationship in the organization.

The remainder of this paper is structured as follows: Section Two contains a brief literature review related to E-CRM, which covers the definition of E-CRM strategy; E-CRM implementation strategy in organizations, E-CRM implementation strategy levels, and E-CRM implementation strategy stages. Section Three provides a conceptual model for E-CRM implementation strategy with detailed descriptions. Finally, the conclusion of our paper is presented in Section Four.

\section{Literature Review}

This section consists of the background to the literature review. Literature such as Definition of ECRM Strategy, E-CRM Implementation Strategy in Organization, and E-CRM Implementation Strategy Level are included. Moreover, E-CRM implementation strategy stages are also discussed.

\section{Definition of E-CRM Strategy}

The key theoretical review basis for E-CRM strategy comes from the relationship with marketing literature. Different definitions of E-CRM have been presented over the years. For instance, Zerbino et al., (2018) noted that the concept of CRM strategy should scheme and arrange the assets of capitals on association construction and maintenance. These should be in line with the client's lifetime value in all portions of business by the use of technologies for dealing knowledge, connections, and joining all functions. Additionally, Sivaraks et al., (2011) suggested that the concept of E-CRM strategy refers to where the organizations begin to migrate from a human intensive model to one which emphasizes several automated interaction opinions. These include the internet and web technology in order to enhance the capability to grow, achieve, and quantify customer relationships with electronic channels. Also, Mahdavi et al., (2008) recommended that the definition of E-CRM should be a group 
of ideas, tools, and procedures that permit an organization to develop the maximum worth from their e-business investment. Assistance industries grow the efficiency of their communication with customers, while at the same time increasing the intimacy of the communication. Additionally, Navimipour and Soltani (2016) also noted that the E-CRM is a collection of concepts and procedures that permit a business to reach the full value for their industry.

Gregory et al (2017) explain that the incorporation of e-commerce marketing capabilities is able to explain how exporters use IT to grow competences and enhance export performance; specifically, how they used the capabilities, RBV theories, and make different distinct contributions to the export marketing literature. Also, Kubina and Lendel (2015) state that community CRM allows customers, through numerous collective platforms, to actively participate in co-operation with its providers. It can most definitely affect and give to the development and adaptation of its products, based on to their needs and requests. From this point, Kubina and Lendel (2015) support the view that the community CRM is a policy for organization of the client relationship in order to control the associations and essential jobs by using new technologies, such as social media.

Recently, Hamidi and Safareyeh (2018) argued that the CRM concept in the electronic environment is a viewpoint and policy of the industry, which is geared for the communication through costumers in their shared ideas; they are confidential and clear in order to deliver worth which is commonly helpful by using mobile applications. Furthermore, Mahdavi et al., (2011) shows that clients can simply apply the internet technology to access material on numerous goods and services available. Organizations can improve the strategy of gathering and examining the clients' data to create superior choices in selling strategies through numerous kinds of information systems, in order to build long-term relationships with customers. They also explain that the concept of CRM is originated on association selling, whose viewpoint lies on enhancing future effectiveness and creating a strategic objective of holding the client over an additional operative management of client relationships (Giannakis-Bompolis and Boutsouki, 2014; Alhawari,2015; Alhawari, 2014; (Tsoutsa et al., 2013). Additionally, Khan et al., (2012) noted that CRM contains rules, actions, procedures, and plans which distribute organizations' capability to combine client connections and, moreover, keep track of all client connected data with novel technologies to entice different clients, and maintain and strengthen ties with existing ones.

In this paper, the author suggested the definition of E-CRM to be the automation of information processing between customers and organizations by using the IT infrastructure. This happens through an interaction between all stages in implementing the E-CRM strategy at different levels (operational, analytical, and collaborative) and connected with E-CRM process (electronic customer acquisition, electronic customer retention, and electronic customer expansion). This is in order to increase the customer orientation strategy, customer intelligence strategy, and knowledge capture strategy to reach to the vision of the E-CRM.

\section{E-CRM Implementation Strategy in an Organization}

In today's enormously competitive environment, organizations are examining novel means of growing revenue by applying the so-called E-CRM strategy. Stein et al., (2013) noted that, in order to grow such benefits from their CRM systems, organizations need to create platforms to access their 
INTERNATIONAL JOURNAL OF ACADEMIC RESEARCH IN BUSINESS AND SOCIAL SCIENCES

Vol. 10, No. 1, Jan, 2020, E-ISSN: 2222-6990 @ 2020 HRMARS

CRM records in a consistent and effective basis. From this point, Sivaraks et al., (2011) stated that ECRM is an essential portion of online distribution and selling. This grows the old-style CRM methods by integrating technologies of advanced electronic networks such as the internet with new technologies. They then connect them with e-business applications into the complete CRM strategy of an organization in order to gain the maximum profit. Additionally, Mahdavi et al., (2008) explain that the increased importance of the E-CRM concept for building and maintaining a loyal relationship with their customers has been frequently emphasized in organizations relying on online presences to communicate.

To help the organization and customer achieve their objectives, IT tools play an important role in building CRM strategies around the world. Accordingly, Becker et al., (2009) states that organizations need to classify previously profitable, but currently inactive, customers and initiate appropriate activities to reactivate those customers. Consequently, the development of IT techniques helps to develop relationships between an organization and its clients. This is through several methods, such as understanding of new structures for e-commerce in order to connect with their customers by providing their products in technology gateways (Bahrami et al 2012).

Gregory et al (2017) suggest that, given the value of IT in global marketing, many organizations have embraced e-commerce as a necessity in exporting. Nevertheless, the way that ecommerce is embedded in business processes differs. Additionally, Zerbino et al., (2018) argues that structures for new technology in CRM strategy viewpoints must be able to back the CRM process with suitable IT resources to build a smooth value for the customer. Additionally, King and Burgess (2008) stress the importance of the E-CRM in organizations and explains the CRM system from a technological perspective; it is a form of IT that enables businesses to acquire new customers, deliver facilities for them, collect and store customer data, and examine this data to deliver a whole opinion of customers' information.

\section{E-CRM Implementation Strategy Level}

A level structure is presented in this section to illustrate how E-CRM strategy extended to incorporate each of the levels. Recently, Pozza et al., (2018) classified the CRM level related to the use of new technologies into three levels. Firstly, Operational CRM, which is applied in center practices, for example auctions and selling, for goals of mechanizing actions to apply new technology revolutions. This focuses chiefly on their capability to gather and examine information based on customer behaviors, to assist in recognizing customer performance, to grow analytical models, to reply with appropriate and efficiently customized communications, and to deliver profitable customers with adapted product and service values. Secondly, Analytical CRM allows businesses to examine all information and transmit it throughout the organization. Finally, Collaborative CRM is applied in outside processes with customers and enables a two-way interactive between the organization and its customers. This is by using new technology to gather customer information each time it interacts with a customer.

Kingshott et al., (2018) noted that the Relationship Marketing (RM) literature highlights the importance of building and maintaining long-term relationships with customers in both business-tobusiness (B2B) and business-to-consumers (B2C) markets. Furthermore, Rapp et al., (2010) views the 
CRM technology strategy as the incorporation of new technology, customer, and organization resources by using the CRM strategy concept, containing both static and operational dimensions, beside a strategic dimension such as customer orientation.

Santouridis and Tsachtani (2015) proposed three levels of CRM related technology, namely operational, analytical, and collaborative. Operational CRM back the organization in its everyday exchanges with its customers by automating marketing operations and providing the organization's staff with all the information required to interact with customers. In analytical CRM, the customer information kept in the data warehouse is studied in order to improve present customers' experiences and important data will prompt the discovery of new patterns connected to the customers. Finally, collaborative CRM gives the whole delivery of customer information over all the likely interaction networks, thus providing the effective integration between the organization's workers.

In another study, Geib et al., (2006) states that CRM systems are a group of information technologies that permit organizations to develop, in touch with customers, and gather, store, and examine customer information to deliver a whole opinion of their customers. CRM software mostly falls into three groups; operational systems apply for automation and improved effectiveness of CRM processes; analytical systems apply for the examination of customer information and knowledge; collaborative systems apply to achieve and mix communication channels and customer communication touch points.

Figure 1 shows the classification of E-CRM strategy level models. It shows how several levels are related to the electronic environment used.

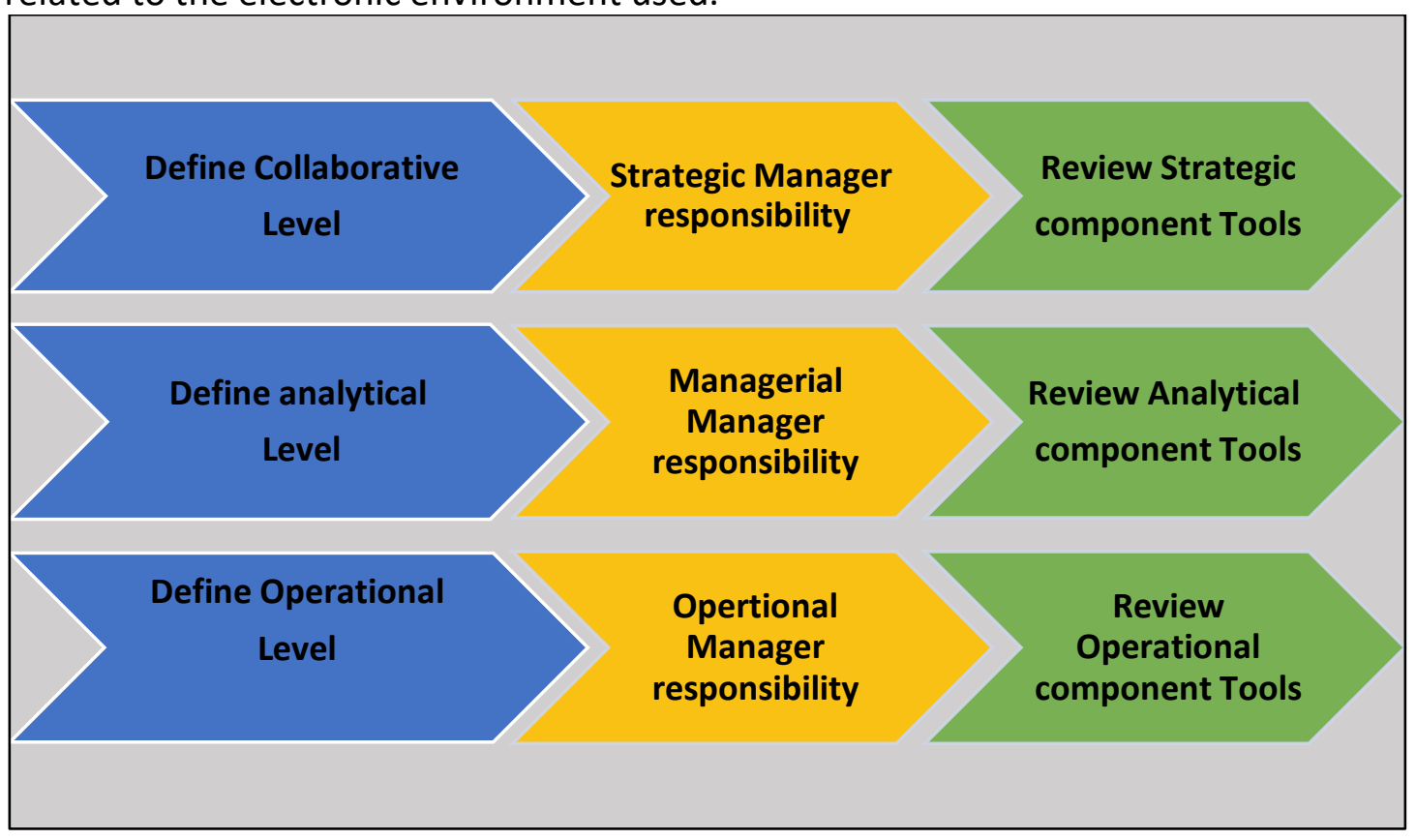

Figure 1: Model 1.E-CRM Strategy Level 
INTERNATIONAL JOURNAL OF ACADEMIC RESEARCH IN BUSINESS AND SOCIAL SCIENCES Vol. 10, No. 1, Jan, 2020, E-ISSN: 2222-6990 @ 2020 HRMARS

\section{E-CRM Implementation Strategy Stages}

A stages structure is presented in this section to illustrate how E-CRM strategy is extended to incorporate each of these stages. Park and Kim (2003) established a model to clarify the information system element and its role in customer practice, containing three phases. Specifically: customer acquisition, retention, and expansion. Firstly, at the acquisition phase staff gather the necessary information through interaction networks and improve the organization database. Secondly, at the retention stage, the organization constructs the association with its customers based on fulfillment creations by proposing high value customized goods and facilities. Finally, at the expansion stage the customer plays an important role in spreading the organization's customer database.

Kingshott et al., (2018) proposed a framework that includes the synthesis of existing studies, revealing that these elements can be best reflected in the following constructs: offline service quality, e-quality, e-satisfaction, trust, commitment, and e-loyalty.

In another study, Sen and Sinha (2011) classified the three approaches of CRM in the IT environment. Namely, customer acquisition, customer retention, and customer profitability. Therefore, IT is applied to achieve different types of customer information over several networks, such as web sites which contain customer favorites and sales information. Additionally, Hadi et al., (2013) proposed the phases of customer knowledge with E-CRM in three categories. Firstly, electronic customer acquisition describes the requirements for improving the number of electronic customers attracted to the organization. Secondly, electronic customer retention highlights the procedure of maintaining a relationship with the current electronic customers within the organization. The final phase is called electronic customer expansion, which discusses extending the relationship between the organization and customers.

Srivastava et al., (2001) suggested that the concept of RBV and marketing explicitly recognizes that customer value originates and exists in the external marketplace. Thus, any effort to integrate RBV and marketing, with a focus on generating (as opposed to sustaining) customer value, therefore needs to determine the marketplace opportunities and configurations of solutions for customer needs. They then need to determine the best resources for the configuration of assets and capabilities required to generate and capture an opportunity.

It is imperative to come to grips with two central but interrelated questions: (1) Where do marketplace opportunities - configurations of solutions for customer needs - come from? (2) Where do the resources - the configuration of assets and capabilities required to generate and capture an opportunity - come from?

The shape below in figure 2 displays the classification of the E-CRM strategy stages model. It shows how several levels are related to the electronic environment used: 
INTERNATIONAL JOURNAL OF ACADEMIC RESEARCH IN BUSINESS AND SOCIAL SCIENCES Vol. 10, No. 1, Jan, 2020, E-ISSN: 2222-6990 @ 2020 HRMARS

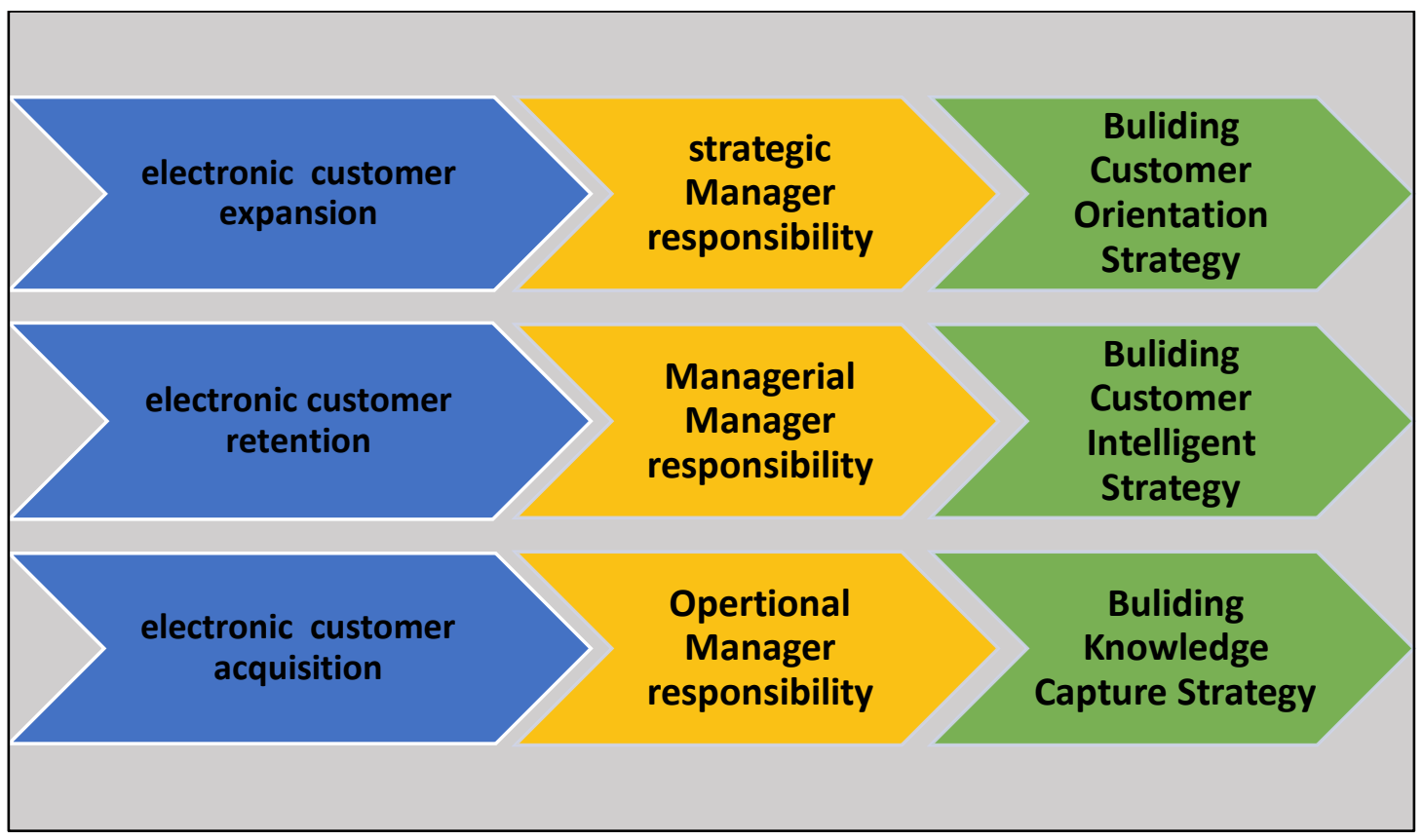

Model 2.E-CRM Strategy stages

Gaining a better relationship with customers in an electronic environment will result from the use of IT within all processes and levels in an organization that, in turn, affect the purchase of goods and services through the internet. This is largely dependent on CRM performance. Therefore, this paper advances research on E-CRM implementation strategy by suggesting a conceptual model which describes the mission of E-CRM. This includes all stages in implementing this E-CRM strategy in different levels (operational, analytical, and collaborative) and connects with E-CRM processes (electronic customer acquisition, electronic customer retention, and electronic customer expansion). This is in order to develop the customer orientation strategy, customer intelligent strategy, and knowledge capture strategy to reach the vision of E-CRM. The identification of such processes will shed light to the online customer relationship in the organization.

\section{Proposed Model for E-CRM Implementation Strategy}

Tying in with prior research, the author is suggesting a conceptual model for E-CRM implementation strategy in order to explain in what way the E-CRM strategy succeeds. Moreover, based on the different literature discussed in previous sections, it has three different E-CRM strategies in different levels, including; operational, analytical, and collaborative. There are also three different E-CRM processes that are used within a particular electronic environment. These E-CRM processes are electronic customer acquisition, electronic customer retention, and electronic customer expansion. The main task in an electronic situation is to successfully consider the customer orientation strategy, customer intelligence strategy, and knowledge capture strategy issues associated with the three ECRM strategy levels and the three E-CRM strategy processes. Thus, the author has suggested and developed a conceptual model for E-CRM implementation strategy into the electronic environment, as displayed in Figure 3. Furthermore, so as to incorporate the theoretical model for E-CRM implementation strategy in electronic environment into shape, systemic support leverages every aspect of the model. Every aspect is completely discussed in this section. 
INTERNATIONAL JOURNAL OF ACADEMIC RESEARCH IN BUSINESS AND SOCIAL SCIENCES Vol. 10, No. 1, Jan, 2020, E-ISSN: 2222-6990 @ 2020 HRMARS

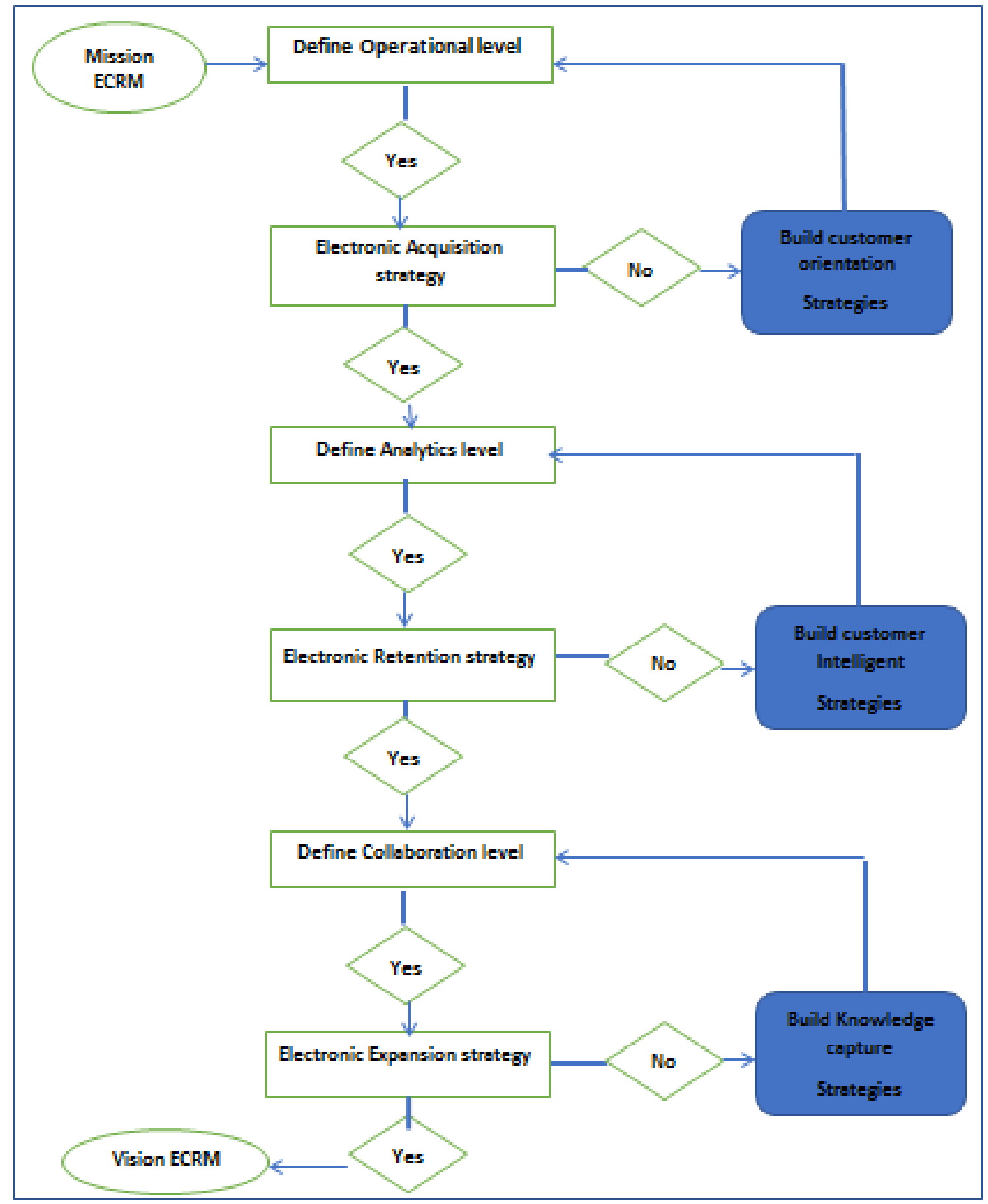

Model 3. E-CRM Implementation Strategy

The first stage for explaining this E-CRM strategy is called Mission E-CRM. In this stage there is a need for rethinking how the existing internet technology can help organizations to manage customer relationships. There is also a need to understand E-CRM key functionality in order to determine the weaknesses and opportunities for this E-CRM functionality, by defining the right channels to include in the E-CRM strategy. 
The second stage defines the operational level of E-CRM. This stage includes sales computerization by internet technologies, marketing computerization by internet technologies, and service computerization by internet technologies. Additionally, the need to collect everything essential specifics then offer electronic facility during electronic customer development is included. If this stage is successful, move into the first phase of the E-CRM process called the Electronic Customer Acquisition, which refers to acquiring new electronic customers by understanding what makes your electronic customers tick. This is done by investing heavily in inbound marketing strategies such as content, building email search engine optimization, and click stream and content information. On the other hand, if this stage is unsuccessful, move into the building Customer Orientation Strategy to review all the applications used in order to improve effectiveness of sales computerization, marketing communication, and service computerization tools. You also need to define the set of organizational values and beliefs and review strategic actions in the operational level of E-CRM.

The third stage defines the analytical level of E-CRM. This stage includes analyzing electronic information pending from each feature of the organization. It produces reports to the organization, including; Client Examination Reports, Sales Analysis Reports, Marketing Analysis Reports, and Channel Analysis Reports. These help the highest administration, selling, sales, and facility workers define the best ways to attend electronic customers through personalized individual views based on purchase history and preferences. These consist of exploratory activities showing the electronic customer's navigation, shopping cart, and shopping pattern. If this stage is successful, move into the second phase of the E-CRM process, which is called Electronic Customer Retention. This phase refers to the retention of existing electronic customers by using electronic customer accounts, improving your electronic customer service, sending engaging emails to electronic customers, and offering a discount or credit to return. On the other hand, if this stage is unsuccessful, move into the building Customer Intelligent Strategy to review all the applications used in order to improve the value added to electronic customers. This can be done by offering customized products and service propositions. You also need to utilize the results of data analysis to create an individualized experience for electronic customers and review strategic actions in the analytical level of E-CRM.

The fourth stage defines the collaboration level of E-CRM. This stage includes the sharing of electronic clients' information amongst numerous industry parts, such as sales groups, selling groups, and practical and maintenance groups, in order to help the organization understand the business goals, identify stakeholders, and choose technology based on business needs. This is accomplished by developing internal resources and skills that permit the development of the system each time change is required. If this stage is successful, move into the third phase of the E-CRM process called Electronic Customer Expansion. This phase provides clear directions to staff in choosing and organizing E-CRM requests in order to expand the relationship with customers. It does this by enhancing electronic service delivery vehicles to match specific needs of electronic customers. On the other hand, if this stage is not successful, move into the building Knowledge Capture Strategy to review the popularity of all the data warehouses used for building a complete customer database, incorporating all the relevant customer knowledge from different departments and external sources. Then review strategic actions in the collaboration level of E-CRM. 
INTERNATIONAL JOURNAL OF ACADEMIC RESEARCH IN BUSINESS AND SOCIAL SCIENCES

Vol. 10 , No. 1, Jan, 2020, E-ISSN: 2222-6990 @ 2020 HRMARS

The final stage refers to reaching the E-CRM vision so as to create a plan for better prediction of electronic customer buying behavior. This stage needs to focus on the organization's future industry aims and careful showing of novel product presents by the standards that greatest suit the complete E-CRM vision of the business.

\section{Conclusion}

The contribution of this study is to richness theoretical aspect related to the study variables, which contributes to foreseeing the future of customer relationship management, which represents of meeting the needs of one of the components of the intellectual capital, that is added to human capital and structural capital in an integrated approach system.

With the fast growth of information technology, the strategy has become a tool that enables uniform and consistent management of the E-CRM of the organization with very good response to electronic customer needs. The literature notes many concepts contributing to the explanation of E-CRM in general. In our paper E-CRM mission, E-CRM level, E-CRM processes, and E-CRM vision were found to be essential for the smooth implementation of E-CRM strategy. Furthermore, for the integration of different stages to be a success, organizations will have to manage the requirements from electronic customers; they have to improve the customer orientation strategy, customer intelligence strategy, and the knowledge capturing strategy. This strategy will manage all the requirements of electronic customers by providing distribution subsystems. This is also integrated with the electronic environment in order to reach the E-CRM vision.

E-CRM strategy assessments support the retention of the track of the implementation functioning, keeping it aligned to the aims of the business in electronic environment. The E-CRM strategy connection through the seller is essential to enhance the growth of original creations in the electronic method. It provides a combined IT infrastructure which is related to both new hardware and software solutions. Furthermore, electronic customer participation and dynamic contribution throughout all stages of the E-CRM strategy implementation makes the process more relaxed and successful, as the electronic customer's lack of interest and passivity can increase the degree of failure of the E-CRM strategy. Therefore, on the basis of the above discussion, this paper recommends organizations use the smooth E-CRM strategy guides to eliminate obstacles during the implementation of E-CRM. It offers the E-CRM strategy as a way of obtaining a competitive advantage.

\section{References}

Alhawari, S., Alryalat, H., Hunaiti, H. (2016). An Empirical Study to Evaluation of Customer Acquisition Processes on Customer Satisfaction, International Journal of Service Science, Management, Engineering, and Technology (IJSSMET), Vol.7, No, 4, pp. 1-20.

Alhawari, S. (2015). Customer Expansion Processes mediating by Knowledge from Customer in the Jordanian Telecommunication Sector to achieve Customer Profitability. International Journal of E-Entrepreneurship and Innovation (IJEEI), Vol.5, No.1, pp.15-31.

Alhawari, S. (2014). Improving decision for banking to support customer knowledge retention: a quantitative study in Jordanian banking sector, International Journal Electronic Customer Relationship Management, Vol. 8, Nos. 1/2/3, pp.119-135.

Ahani, A., Ab. Rahim, N. Z., and Nilashi, M. (2017). Forecasting social CRM adoption in SMEs: A combined SEM-neural network method, Computers in Human Behavior Vol.75, pp.560-578. 
INTERNATIONAL JOURNAL OF ACADEMIC RESEARCH IN BUSINESS AND SOCIAL SCIENCES

Vol. 10, No. 1, Jan, 2020, E-ISSN: 2222-6990 @ 2020 HRMARS

Bahari, F. T., and Elayidom, S. M. (2015). An Efficient CRM-Data Mining Framework for the Prediction of Customer Behavior, Procedia Computer Science, Vol.46, pp.725-731.

Bahrami, M., Ghorbani, M., and Arabzad, M. S. (2012). Information Technology (IT) as An Improvement Tool for Customer Relationship Management (CRM), Procedia Social and Behavioral Sciences, Vol.41, pp. 59-64.

Becker, J. U., Greve, G., and Albers, S. (2009). The impact of technological and organizational implementation of CRM on customer acquisition, maintenance, and retention, Intern. J. of Research in Marketing Vol.26, pp. 207-215.

Geib, M., Kolbe, L. K., and Brenner, W. (2006). CRM collaboration in financial services networks: a multi-case analysis, Journal of Enterprise Information Management. Vol.19, pp. 591-607.

Giannakis-Bompolis, C., and Boutsouki, C. (2014). Customer Relationship Management in the Era of Social Web and Social Customer: An Investigation of Customer Engagement in the Greek Retail Banking Sector, Procedia - Social and Behavioral Sciences, Vol.148, pp.67-78.

Giannakis-Bompolis, C., and Boutsouki, C. (2014). Customer Relationship Management in the Era of Social Web and Social Customer: An Investigation of Customer Engagement in the Greek Retail Banking Sector, Procedia Social and Behavioral Sciences, Vol148, pp.67-78.

Hadi, W. M., Al-Widian, J., and Alhawari, S. (2013). An Integrated Model for Knowledge Management and Electronic Customer Relationship Management, The Journal of American Science, Vol.9, No.11, pp. 440-447

Hamidi, H., and Safareyeh, M. (2018). A model to analyze the effect of mobile banking adoption on customer interaction and satisfaction: a case study of m-banking in iran, Telematics and Informatics, https://doi.org/10.1016/j.tele.2018.09.008.

King, S. F., and Burgess, T. F. (2008). Understanding success and failure in customer relationship management, Industrial Marketing Management, Vol.37, pp.421-431.

Khan, A., Ehsan, N., Mirza, E., Sarwar, S. Z. (2012). Integration between Customer Relationship Management (CRM) and Data Warehousing, Procedia Technology 1, pp. 239-249

Kaimer, F., and Brune, P. (2018). Return of the JS: Towards a Node.js-Based Software Architecture for Combined CMS/CRM Applications, Procedia Computer Science Vol.141, pp.454-459.

Kubina, M., and Lendel, V. (2015). Successful Application of Social CRM in The Company, Procedia Economics and Finance, Vol.23, pp.1190-1194.

Mahdavi, I., Cho, N., Shirazi, P., and Sahebjamnia, N. (2008). Designing evolving user profile in e-CRM with dynamic clustering of Web documents, Data and Knowledge Engineering, Vol.65, pp.355372.

Mahdavi, I., Movahednejad, M., and Adbesh, F. (2011). Designing customer-oriented catalogs in eCRM using an effective self-adaptive genetic algorithm, Expert Systems with Applications, Vol. 38, pp.631-639.

Mekkamol, P., Piewdang, S., and Untachai, S. (2013). Modeling e-CRM for Community Tourism in Upper Northeastern Thailand, Procedia Social and Behavioral Sciences, Vol.88, pp. 108-117.

Navimipour, N., and Soltani, Z. (2016). The impact of cost, technology acceptance and employees 'satisfaction on the effectiveness of the electronic customer relationship management systems, Computers in Human Behavior, Vol.55, pp. 1052-1066

Park, C. H., and Kim, Y. G. (2003). A framework of dynamic CRM: linking marketing with information Strategy. Business Process Management Journal, Vol. 9, No. 5, pp.652-671. 
INTERNATIONAL JOURNAL OF ACADEMIC RESEARCH IN BUSINESS AND SOCIAL SCIENCES

Vol. 10, No. 1, Jan, 2020, E-ISSN: 2222-6990 @ 2020 HRMARS

Payne, A., and Frow, P. (2005). A strategic framework for customer relationship management. Journal of Marketing, Vol.69, No. 4, pp.167-176.

Pozza, I. D., Goetz, O., Sahut, J. M. (2018). Implementation effects in the relationship between CRM and its performance, Journal of Business Research, Vol.89, pp. 391-403

Rapp, A., Trainor,K. J., and Raj, A. (2010). Performance Implications of Customer-linking Capabilities: Examining the Complementary Role of Customer Orientation and CRM Technology, Journal of Business Research, Vol.63, No. 11, pp. 1229-1236.

Reddick, C. G. (2011). Customer Relationship Management (CRM) technology and organizational change: Evidence for the bureaucratic and e-Government paradigms, Government Information Quarterly, Vol.28, pp.346-353.

Sivaraks, P., Krairit, D., and Tang, J. C. (2011). Effects of e-CRM on customer-bank relationship quality and outcomes: The case of Thailand, Journal of High Technology Management Research, Vol. 22, 141-157.

Sen, A., and Sinha, A. P. (2011). IT alignment strategy for customer relationship management, Decision Support Systems, Vol.51, pp.609-619.

Santouridis, I., \& Tsachtani, E. (2015). Investigating the impact of CRM resources on CRM processes: a customer life-cycle based approach in the case of a Greek bank. Procedia Economics and Finance, 19, 304-313.

Stein, A. D., Smith, M. F., Lancioni, R. A. (2013). The development and diffusion of customer relationship management (CRM) intelligence in business-to-business environments, Industrial Marketing Management, Vol. 42, No. 6, pp.855-861.

Trainor, K., Andzulis, J. M., Rapp, A., and Agnihotri, R. (2013). Social media technology usage and customer relationship performance: A capabilities-based examination of social CRM, Journal of Business Research, Vol. 67, No. 6, pp.1001-1008.

Varajão, J., and Cruz-Cunha, M. M. (2016). Main motivations for CRM adoption by large Portuguese companies - a Principal Component Analysis, Procedia Computer Science, Vol.100, pp. 12691279.

Yu, X., Nguyen, B., Han, S. H., Chen, C.-H. S., \& Li, F. (2015). Erratum to: Electronic CRM and perceptions of unfairness. Information Technology and Management, Vol.16, No.4, 351-363.

Zerbino, P., Aloini, D., Dulmin, R., and Mininno, V. (2018). Big Data-enabled Customer Relationship Management: A holistic approach, Information Processing and Management, Vol.54,No.5, pp. 818-846.

Mokhtar, W. N. H. W., Shaifuddin, N., Yu, H., Saman, W. S. W. M., \& Baba, N. (2018). The Importance of Measurement and Evaluation Works in Academic Libraries. International Journal of Academic Research in Progressive Education and Development, 7(3), 363-377.

Jarrah, M. A. AL, Alomari, G. I., Alhawari, S. F., Malek, \& Alharafsheh. (2020). Building a Conceptual Model for E-CRM Implementation Strategy. International Journal of Academic Research in Business and Social Sciences, 10(1), 180-195.

Tsoutsa, S., Kedraka, K., \& Papastamatis, A. (2013). Secondary education Greek philologists as adult learners on ICT. Multilingual Academic Journal of Education and Social Sciences, 1(2), 47-54.

Al Shbail, M. O. (2018). A Theoretical Discussion of Factors Affecting the Internal Audit Quality in Jordanian Public Shareholding Companies, International Journal of Academic Research in Accounting, Finance and Management Sciences 8 (2): 218-227. 